\title{
SIMULATION OFCASCADED H-BRIDGE MULTILEVEL INVERTER FOR GRID CONNECTED PHOTOVOLTAIC SYSTEM USING DSAE PWM
}

\author{
M.S. SIVAGAMA SUNDARI ${ }^{1} \&$ D.PERIYASAMY ${ }^{2}$ \\ ${ }^{1}$ Assistant Professor, Department of EEE, Amrita College of Engineering and Technology, Nagercoil, TamilNadu, India \\ ${ }^{2}$ Assistant Professor, Department of EEE, Imayam College of Engineering, Trichy, TamilNadu, India
}

\begin{abstract}
A single-phase Cascaded H-bridge eleven level inverter for grid-connected photovoltaic system was developed in this paper. The discrete sine area equalization pulse width modulation technique was used for modeling. The particle swarm optimization algorithm was used for eliminating the harmonic distortion.The performance of the inverter was found to be better for the discrete sine area equalization pulse width modulation technique. The harmonic spectrum and output waveforms for various load conditions were obtained for both DSAE PWM and OHSW-PWM techniques. It was also found that DSAE PWM technique can handle load variations by maintaining total harmonic distortion.

KEYWORDS: Multilevel Inverter, Cascaded H-bridge Inverter, Total Harmonic Distortion, DSAE PWM, SHE-PWM, MATLAB
\end{abstract}

Received: Mar 07, 2020; Accepted: Mar 27, 2020; Published: Jul 28, 2020; Paper Id.: IJMPERDJUN2020493

\section{INTRODUCTION}

In the recent years, the demand for clean and green energy requires high quality output power with low switching losses. It is also seen that the soft switching technology develop showing that the demand further increases by improving efficiency. This trend is expected to continue in coming years because the energy produced by renewable sources is expected to satisfy $20 \%$ and $50 \%$ of the total needs in 2020 and 2050 respectively. It is also witnessed that among these renewable energy sources, solar photovoltaic energy is found to be a promising energy.

An important consequence of this situation is a change of the electric power system from the present one, consisting of a relatively low number of very high power ac generators, to a distributed one, characterized by an extremely large number of small and medium power dc and ac generators supplied by renewable energy sources connected to the grid through electronic power converters, the latter adapting the produced energy to grid specifications.

This new scenario introduces many technical, economic, and political challenges because it is changing the way in which the electrical energy resources (generation, transmission and distribution networks) are designed and managed. From the technical viewpoint, the use of electronic power converters introduces new and challenging issues, including increased topological complexity, additional power losses, and electromagnetic interferences, thus reducing the overall quality of service, efficiency, and network stability.

Franquelo and Rodriguez [1] introduced the pulse width modulated (PWM) multilevel inverter is an effective alternative to current inverter topologies and provides an introduction of the modeling techniques and the most common modulation strategies. Lai and Peng [2] have described three recently developedmultilevel voltage 
source converters and the techniques to balance the voltage between different levels in multilevel converters.Rodriguez,Lai and Peng [3] have described the most relevant control and modulation methods developed for this family of converters: multilevel sinusoidal pulsewidth modulation, multilevel selective harmonic elimination, and space-vector modulation. Tolbert and Peng [4] have experimentally demonstrated that traditional 2-level high frequency pulse width modulation inverters for motor drives have several problems associated with their high frequency switching and two different multilevel topologies are identified for use as a converter for electric drives.Rodriguez and Dixon [5] have introduced the PWMregenerative rectifiers with reduced input harmonics and improved power factor. In early stages, multilevel active rectifier were employed mainly in high-voltage high-power industrial and traction applications because they distribute the applied voltage among a number of cascaded power devices, thus overcoming their voltage limits and allowing the elimination of output transformers in medium-high voltage systems. Since their output voltage is a modulated staircase, they outperform two-level PWM inverters in terms of total harmonic distortion (THD), without the use of bulky expensive and dissipative passive filters has been demonstrated in [6,7]. Multilevel inverters in the field of renewable energies, including photovoltaic (PV) generators has been described in [8, 9]. Calais and Agelidis [10,19] have developed Unipolar SPWM full-bridge with transformer less grid connected inverter, a lot of depth researches, where new freewheeling paths are constructed to separate the PV array from the grid in the freewheeling period.

Ertl and Kolar [11] have proposed a novel multicell DC-AC converter for applications in renewable energy systems. Alonso and Sanchis [12] have introduced a new control method and proportional PWM modulation of the cascaded H-bridge multilevel converter for grid-connected photovoltaic systems and this control makes each H-bridge module supply different power levels, allowing therefore for each module an independent maximum power point tracking of the corresponding photovoltaic array. Walker and Sernia [13] have proposed an alternative topology of nonisolated perpanel dc-dc converters connected in series to create a high voltage string connected to a simplified dc-ac inverterand buck, boost, buck-boost, and $\mathrm{Cu}^{\prime} \mathrm{k}$ converters are considered as possible dc-dc converters that can be cascaded.Rahiman and Kumar [14] have developed a fifteen level cascaded H-BridgeConfiguration,equal dc voltages areselected for each of the units, with step modulation and fundamental frequency switching which has reduced conduction loss and switching loss.Kang and Park [15] have developed multilevel PWM inverters suitable for the use of stand-alone photovoltaic power grid-connected inverters for photovoltaic modules. Alepuz [16] have described a three level inverter that can be used to interface distributed dc energy sources with a main ac grid or as an interface to a motor drive. Ozdemir and Tolbert [20] have proposed a five level DMLI fundamental frequency switching strategy for three phase stand-alone photovoltaic systems by selecting the switching angles such that the lower order harmonics are eliminated. Besides being able to maximize the power obtained from the PVAs, the multilevel converter usually presents the advantages of reducing the device voltage stress, being more efficient and generating a lower output a voltage harmonic distortion. Among the following three main families of multilevel converters; diode-clamped, capacitor-lamped and cascaded H-Bridge, the latter is usually considered in the literature for PV applications [17,18].

Fortunato [21] have proposed an improved maximum power point tracking with better performance to solve a fast changing irradiation problem. Shanthi.B[22] have proposed multilevel inverter control strategies are implemented in real time using FPGA for linear and non-linear loads.Shuitao yang [23] have introduced Hळ controller with explicitrobustness in terms of grid-impedance variations to incorporatethe desired tracking performance and stability margin. F.T. Josh [24] have proposed multilevel inverter in the field of renewable energies, reduces output filter dimensions and influence of perturbations caused by cloud darkening or seasonal variations. Jun Mei, Bailuxiao[25] have proposed an improved phase 
disposition pulse width modulation (PDPWM) for a modular multilevel inverter which is used for Photovoltaic grid connectionto achieve dynamic capacitor voltage balance without the help of an extra compensation signal.Lewicki\&Morawiec [26] suggested a control strategy of DC-linkvoltages for a seven-level CHB inverter. In this method SVM strategy has been used to generate the output voltage vector properly but the DC-link voltages are not balanced.

Closed loop operation of OHSW-PWM technique can maintain the modulation index of the output voltage up to an extent. However, this method failed to maintain the THD with the load variations and fundamental rms output voltage. The single-phase cascaded H-bridge eleven level inverter for a grid-connected photovoltaic system with discrete sine area equalization pulse width modulation technique has been modeled and analyzed for estimating various responses.

\section{CASCADED H-BRIDGE INVERTER TOPOLOGY}

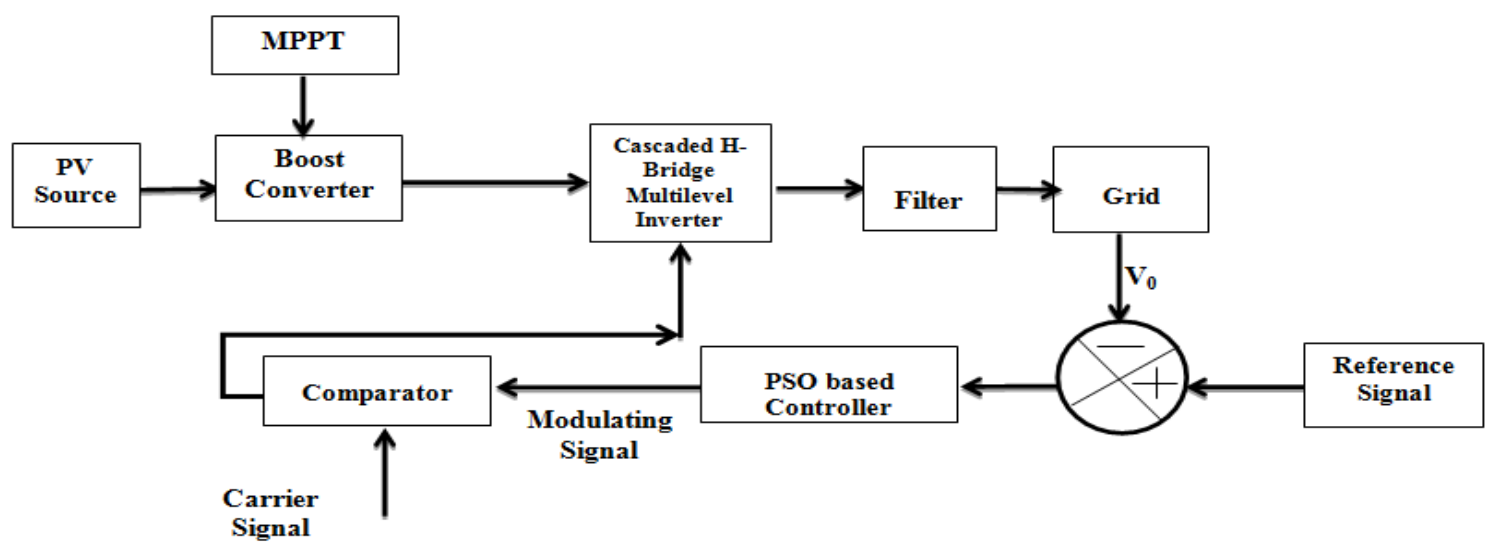

Figure 1: Block diagram of Cascaded H-bridge inverter topology with DSAE PWM

The block diagram of a proposed CHB inverter topology with DSAE PWM is shown in figure 6.6. This system consists of several PV modules, DC/DC power converter, a multilevel DC/AC power inverter and a filter. The PV modules arrangements are considered with multi-string technology. Each string of the PV array is connected to DC/DC boost converter with MPPT. As the irradiance level is inconsistent throughout a day, the amount of power generated by the PV modules is always changing with weather conditions. The $\mathrm{P} \& \mathrm{O}$ algorithm is used to extract maximum power from $\mathrm{PV}$ array. The DC power from the PV array is boosted using DC-DC boost converter with DC bus capacitors. The output of these converters is the DC power supply of the multilevel DC/AC power converter. The output of eleven level inverter is $\mathrm{AC}$ voltage, which is connected to grid system utility feeder through filtering inductor.The injected current must be sinusoidal with low harmonic distortion. The power factor is also maintained at near unity. PSO algorithm is employed for optimizing non-linear objective function and finding out the optimal switching angles for the MLI switches. The objective of DSAE PWM is to eliminate lower order harmonics. The DSAE PWM with closed loop control using PSO algorithm has been simulated using MATLAB software. 


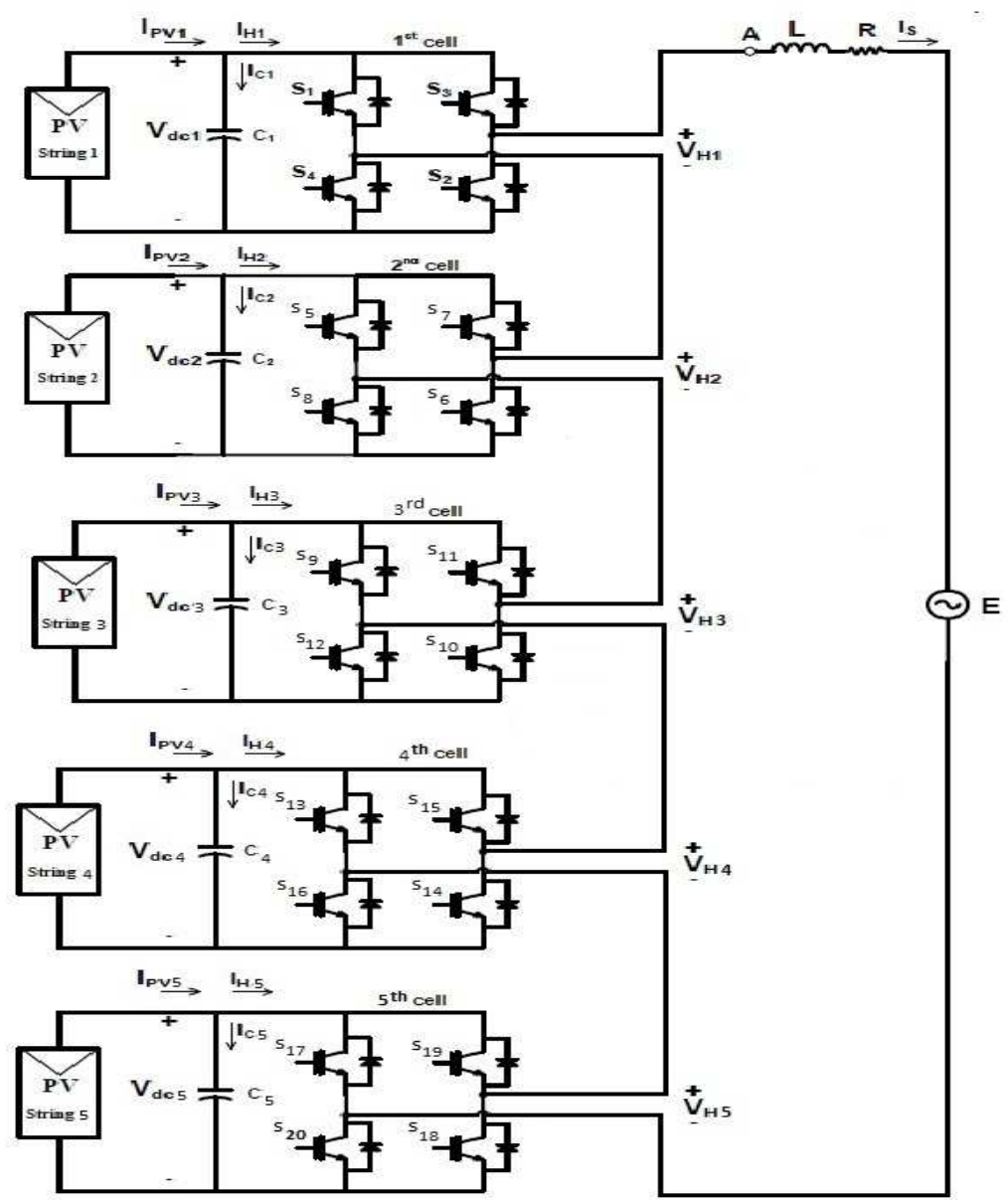

Figure 2: Cascaded h-bridge inverter topology for grid connected pv system

A schematic diagram of CHB inverter topology of grid connected PV system is shown in figure 6.1.The CMLI topology consists of ' $\mathrm{n}$ ' number ofH-bridge inverters connected in series. Each DC-link is fed by a short string of PV panels. By considering cells with the same DC-link voltage, the inverter can synthesize an output voltage $V_{H T}$ with ' $n$ ' levels. This high-quality voltage enables the reduction of the harmonics in the generated current, reducing the filtering effort at the input. This topology can inject sinusoidal input currents with unity power factor to the grid, even under conditions of unequal solar radiation of the string of PV cells. The CMLI is connected to grid through inductance filter, which is used to reduce the switching harmonics.

\section{MODELING ON DSAE PWM}

The Discrete Sine Area Equalization PWM technique is capable of handling load variations while maintaining THD. The concept behind this technique is to equalize the area under the multilevel output voltage to that of the area under the sine waveform of the desired fundamental voltage at discrete time periods. For different load variations, a linear equation is formulated in such a way that sine area gets equalized with the multilevel output voltage area and by solving that equations the respective time periods $t_{i 1}, t_{i 2}$ are obtained. The time periods $t_{i 1}, t_{i 2}$ can be controlled to achieve the different area under the output voltage which is directly proportional to the maximum value of the fundamental voltage.

The switching angles for the proposed DSAE PWM technique is designed by using the basic electrical equations related to the alternating current. Generally, the entire system can be divided into four steps. 
First step in the proposed methodology is to finding out the discrete time periods in which the sine area and the multilevel inverter output voltage area is made to be equal. As shown in the fig. 1 , the discrete time periods $\mathrm{t}_{\mathrm{i}} \mathrm{is}$ the time at which sine waveform reaches the multilevel inverter input DC source voltage $\mathrm{V}_{\mathrm{dc}}$ where irepresents each level of the multilevel inverter. The time periods $\mathrm{t}_{\mathrm{i}} \mathrm{is}$ calculated by using the following equations.

$\mathrm{Vi}=\mathrm{Vm} \sin (\omega \mathrm{t})(1)$

$\mathrm{V}_{\mathrm{i}}$ is the instantaneous voltage of the sine wave, $\mathrm{V}_{\mathrm{m}}$ is the maximum voltage of the desired sine waveform, $\omega$ is the angular frequency of the desired sine waveform. The equation (1) can be rearranged to obtain the discrete time periods.

$$
t_{i}=\sin ^{-1}\left(\frac{V_{i}}{V_{\mathrm{m}}}\right) / \omega(2)
$$

In the above equation (2) $\mathrm{V}_{\mathrm{i}}$ is substituted with the respective $\mathrm{V}_{\mathrm{dc}}$ for different levels. Hence $\mathrm{V}_{\mathrm{dc}}$ is assumed to be constant for all the five H-bridge circuits. So, for each level, the instantaneous voltage would be

$$
\mathrm{V}_{\mathrm{i}}=\mathrm{V}_{\mathrm{dc}} * \mathrm{i}(3)
$$

Second step is to find out the area under the sine waveform between the discrete time periods $t_{(i-1)}$ and $t_{i}$, the area under the curve is obtained by integrating the sine waveform between the respective time periods.

$$
A_{i}=V_{m} \int_{t_{i=1}}^{t_{I}} \sin (\omega t)
$$

Where $A_{i}$ is the segmentation area which is the area under the sine curve between the time periods $t_{(i-1)}$ and $t_{i}$.

With the segmentation area founded out, the next step is to find out the $t_{i 1}$ and $t_{i 2}$ such a way that the segmentation area equals to the area under the multilevel inverter output voltage at the time periods $t_{i . .}$ In order to find out $t_{i 1}$, $t_{i 2}$, a system of two linear equations are formulated and by solving that the time periods $t_{i 1}$ and $t_{i 2}$ are obtained.

$$
\begin{aligned}
& V_{d e} *(i-1) * t_{i 1}+V_{d e} * i * t_{i 2}=A_{i} \\
& t_{i d}+t_{i 2}=t_{i}=t_{i-1}
\end{aligned}
$$

In the equations (5) and (6), $A_{i}$ and $t_{i}$ are founded out from the previous steps and $V_{d c}$ is the constant input DC source voltage. $t_{i 1}$ and $t_{i 2}$ are the unknowns to be found. As the above linear system has two unknowns and two equations, it can be converted in to matrix form as follows.

$$
\begin{aligned}
& A i=\left(\begin{array}{ll}
V_{d e} *(i-1) & V_{d e} * i
\end{array}\right)\left(\begin{array}{c}
t_{i 1} \\
t_{i 2}
\end{array}\right) \\
& B=\left(\begin{array}{c}
A_{i} \\
t_{i 1}+t_{i 2}
\end{array}\right)
\end{aligned}
$$


where $\mathrm{A}$ is the Input matrix and B is the output matrix.

From the above matrices, the following matrix equation (9) is formed, Where $\mathrm{X}$ is the unknown to be found out.

$$
X=A i^{-1} B
$$

By solving the equation (9), unknown's $\mathrm{t}_{\mathrm{i} 1}$ and $\mathrm{t}_{\mathrm{i} 2}$ is obtained.

$$
X=\left(_{t_{i 2}}^{t_{i 1}}\right)
$$

Finally, the switching time $\alpha_{\mathrm{i}}$ iscalculated with $\mathrm{t}_{\mathrm{i} 1}$ and $\mathrm{t}_{\mathrm{i} 2}$ values using the equation.

The switching time $\alpha_{\mathrm{i}}$ are calculated only for half cycle of the output voltage because of the switching time will be same for both negative and positive half cycle (quarter wave symmetry). The switching time $\alpha_{\mathrm{i}}$ can be applied to the noload condition, but if the load gets increased in the circuit which increases the current and voltage drop in the source impedance of the circuit. This leads to decrease in the output voltage from the desired output voltage. The percentage deviation in output voltage from the desired voltage is called Modulation Index m.

$$
m=\frac{V_{0}}{V_{d}}
$$

$\mathrm{V}_{\mathrm{o}}$ is the output voltage at the inverter load side, $\mathrm{V}_{\mathrm{d}}$ is the desired output voltage at the load side. As a voltage source, multilevel inverter should maintain modulation index at unity for different load variations. In order to achieve that, the output voltage is continuously measured at the load side and modulation index is calculated. If the modulation index is not at the unity, then the switching time is again calculated from the Step 3 by substituting $\mathrm{V}_{\mathrm{dc}}=\mathrm{V}_{\mathrm{dc}} * \mathrm{~m}$ in the equation (5). The new switching time regains the voltage and maintains the modulation index. This process continuously monitors and maintains the modulation index at unity.

\section{PARTICLE SWARM OPTIMIZATION ALGORITHM}

The particle swarm optimization (PSO) algorithm has been employed for estimating the switching angles $\theta_{1}, \theta_{2}, \theta_{3}, \theta_{4}$ and $\theta_{5}$ which will lead to the $5^{\text {th }}, 7$ th, 11 th and $13^{\text {th }}$ lower order harmonics eliminationin a multilevel inverter. An objective function is used for this purpose,. This function uses the set of five trigonometric transcendental equations containing the switching angles $\theta_{1}, \theta_{2}, \theta_{3}, \theta_{4}$ and $\theta_{5}$.

\section{SIMULATION RESULTS}

The open loop and closed loop topology of cascaded h-bridge eleven level inverter topology using DSAE PWM are carried out using MATLAB/Simulink software. The elements and the parameters considered for simulation are presented in Table 1 for the cascaded h-bridge eleven level inverter topology for grid connected PV system for various load conditions.The system is simulated with a switching frequency of $5 \mathrm{kHz}$. The PSO algorithm is developed and simulated wave forms of output voltage, output current and total harmonic distortion are shown for open loop and closed loop response.

Table 1: Parameters of the Cascaded H-Bridge Inverter

\begin{tabular}{|c|l|c|}
\hline Symbols & \multicolumn{1}{|c|}{ Parameters } & Values \\
\hline $\mathrm{S}_{\mathrm{i}}$ & Solar Insolation & $1000 \mathrm{~W} / \mathrm{m}^{2}$ \\
\hline $\mathrm{T}$ & Temperature & $25^{\circ} \mathrm{C}$ \\
\hline $\mathrm{N}_{\mathrm{c}}$ & Number of cells per module & 36 \\
\hline
\end{tabular}




\begin{tabular}{|c|l|c|}
\hline $\mathrm{N}_{\mathrm{ps}}$ & Number of Parallel strings & 66 \\
\hline $\mathrm{N}_{\mathrm{ss}}$ & $\begin{array}{l}\text { Number of series connected modules per } \\
\text { strings }\end{array}$ & 11 \\
\hline $\mathrm{f}_{\mathrm{s}}$ & Switching frequency & $5 \mathrm{KHZ}$ \\
\hline $\mathrm{V}_{\mathrm{g}}$ & Grid Voltage & $230 \mathrm{~V}$ \\
\hline $\mathrm{V}_{\mathrm{o}(\mathrm{pv})}$ & PV array output voltage & $36 \mathrm{~V}$ \\
\hline $\mathrm{f}_{\mathrm{f}}$ & Filter fundamental frequency & $50 \mathrm{HZ}$ \\
\hline $\mathrm{C}$ & DC link capacitor & $2200 \mu \mathrm{f}$ \\
\hline $\mathrm{L}$ & Load Inductor & $10 \mathrm{mH}$ \\
\hline $\mathrm{R}_{\mathrm{L}}$ & Load resistor & $10 \mathrm{Ohm}$ \\
\hline $\mathrm{N}$ & Number of Levels & 11 \\
\hline
\end{tabular}

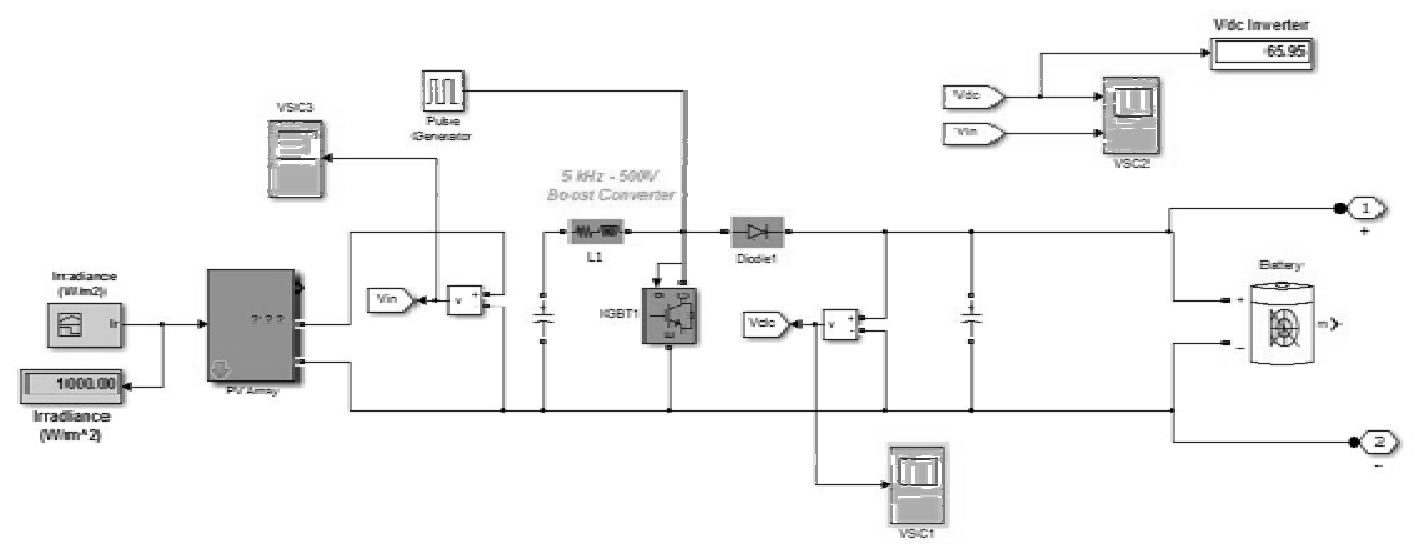

Figure 3: Simulation model of grid connected PV system

The Simulation model of grid connected PV system is shown in fig.3. The output voltage of the PV array is obtained by load current based on the solar irradiation level.The output voltage waveformof the PV array is shown in Fig.4. The PV output of $36 \mathrm{~V}$ is obtained by adjusting the temperature value.The PV array is connected with boost converter. The boost converter helps to improve the voltage gain observed by the PV array.

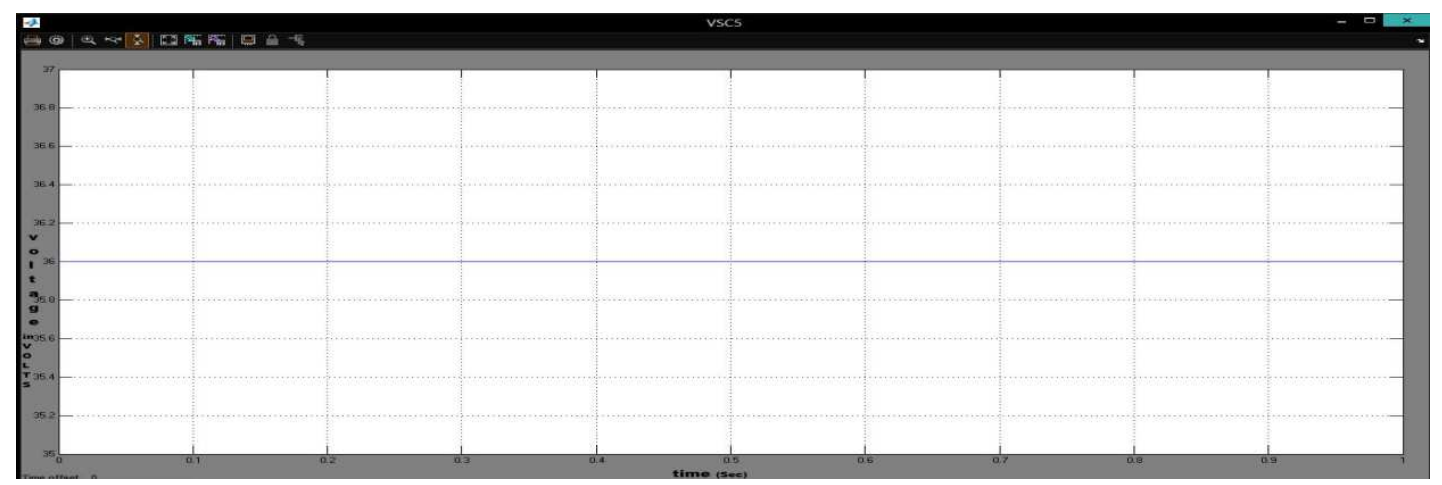

Figure 4: Output voltage waveform of PV Array

MPPT technique is used for maximum energy tracking from the Sun, so for this purpose various maximum power point tracking methods are used. Here perturb and observe algorithm is used so that the sign of the last perturbation and the sign of the last increment in the power are used to decide what the next perturbation should be. If there is an increment in the power, the perturbation should be kept in the same direction and if the power decreases, then the next perturbation 
should be in the opposite direction and the algorithm is implemented. The process is repeated until the MPP is reached. Then the operating point oscillates around the MPP.

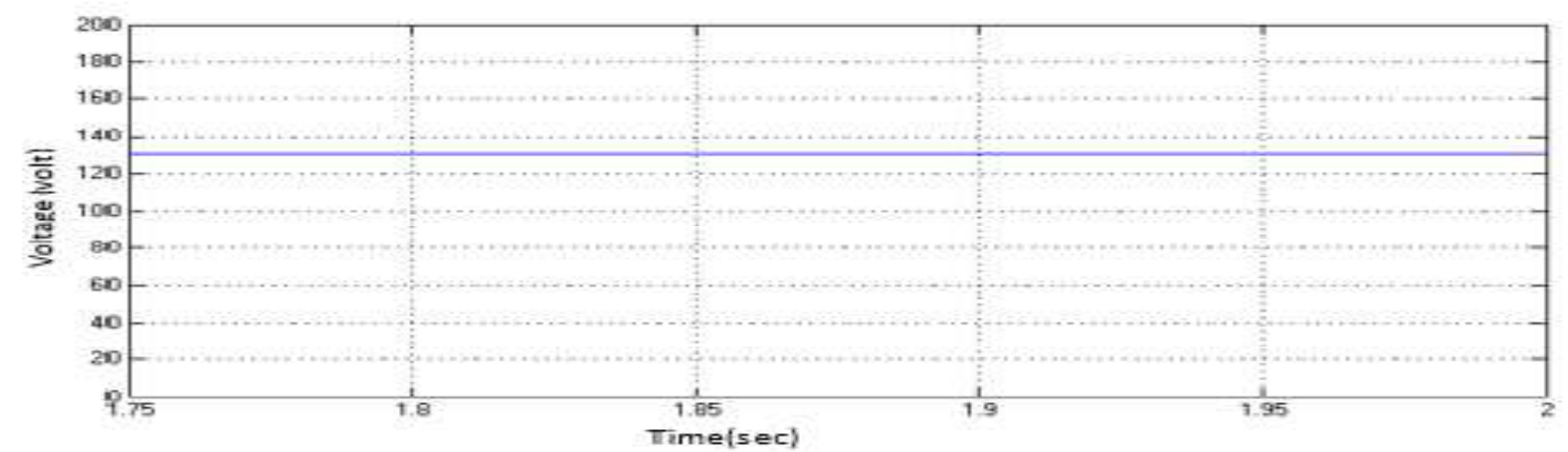

Figure 5: Output Voltage Waveform of MPPT DC/DC Converter

The output voltage waveform of MPPT DC/DC converter is shown in Fig.5. The output voltage depends upon the input voltage and this MPPT is suitable for improving the voltage level from $130 \mathrm{~V}$.

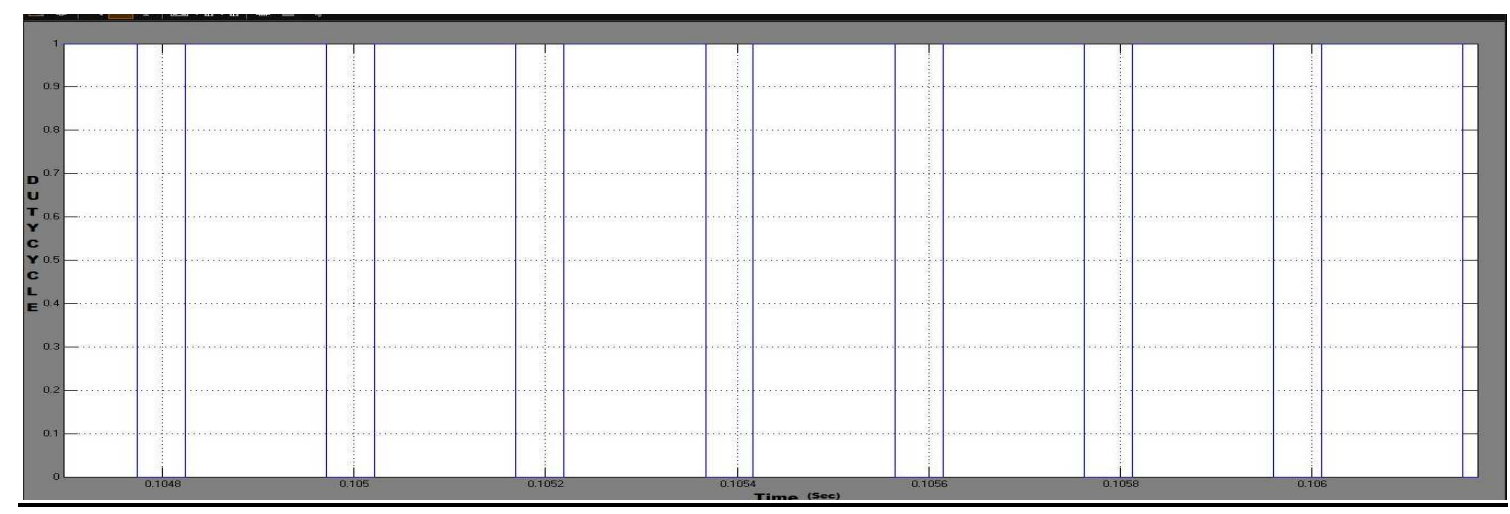

Figure 6: PWM signals for DC/DC Boost Converter

The PWM signals for DC/DC boost converter is shown in fig.6.The boost converter is permitted to work in continuous mode and the multilevel inverter switching sequence uses DSAE PWM technique. The duty cycle varies from 0 to 1 .

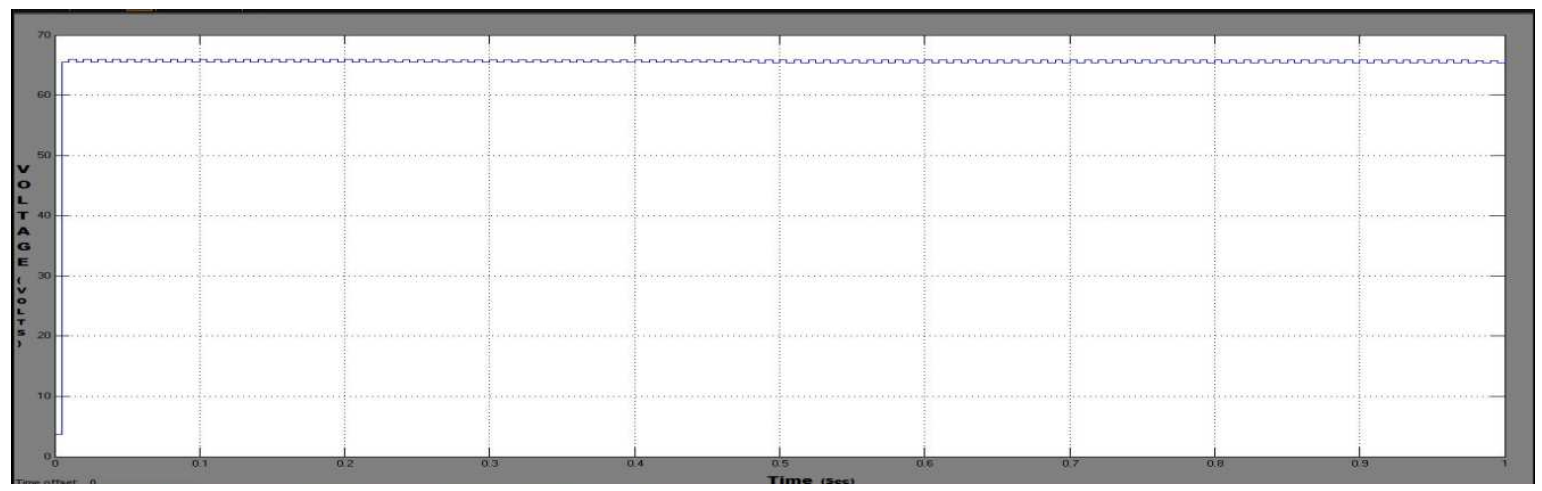

Figure 7: Input DC voltage from grid connected PV system

The output from the PV array is unregulated and so boost converter is used to regulate the dc output. The switches 
used involve switching losses thereby decreasing the efficiency. The regulated dc input voltage from grid connected PV system is $65.95 \mathrm{~V}$ and it is given to the five h-bridge levels of the proposed cascaded h-bridge eleven level inverter topology. It is shown in fig.7.

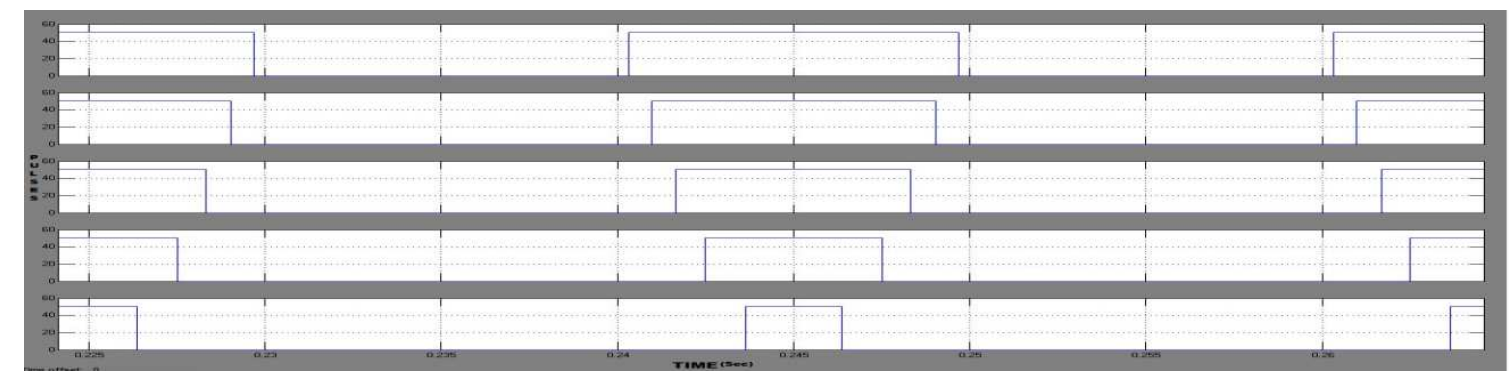

Figure 8: PWM signals for Cascaded h-bridge eleven level inverter

The PWM signals for cascaded h-bridge eleven level inverter are shown in fig.8. PWM generators are used in control of both eleven level cascade H-bridge multilevel inverter and boost converter.

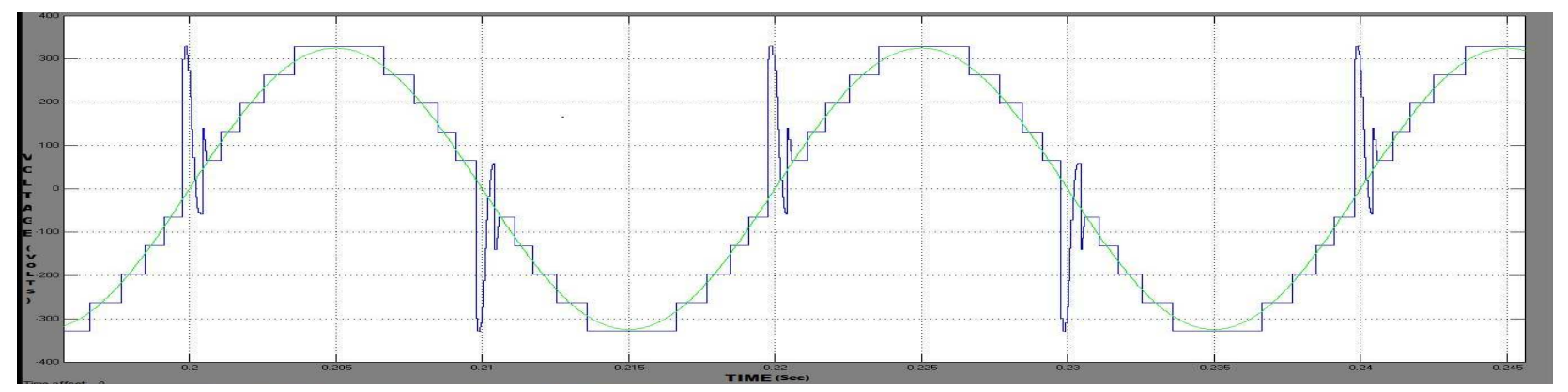

Figure 9: Output voltage waveform of Cascaded h-bridge eleven level inverter

The output voltage and output current of cascaded h-bridge eleven level inverter has eleven levels. The fundamental frequency of inverter is $50 \mathrm{~Hz}$. Due to parallel connection, voltage obtained is around $330 \mathrm{~V}$ are shown in fig.9.

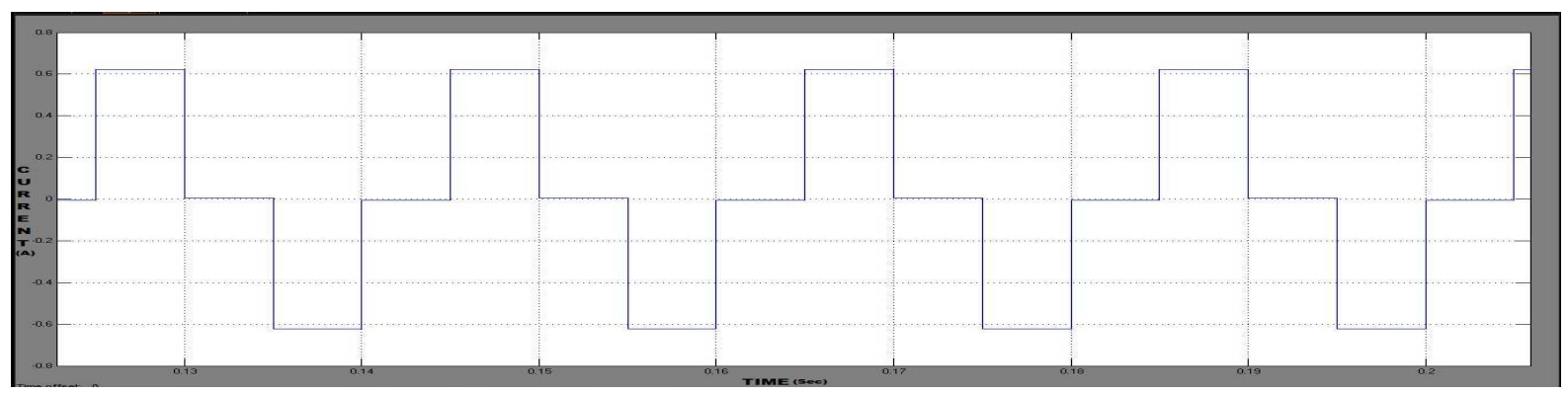

Figure 10: Output current waveform of Cascaded h-bridge eleven level inverter

The output current of cascaded h-bridge eleven level inverter is $0.6 \mathrm{~A}$ is shown in fig.10. The output current depends upon the connected load. For finding the switching angles, it is suitable to use the Fourier coefficients technique to eliminate some harmonics.The number of harmonics to be eliminated is equal to the number of switching angles are obtained.The percentage of THD variations with variable load are shown in fig.11 and 12.The total harmonic distortion of cascaded h-bridge eleven level inverter output current is around $21.04 \%$ for conventional method and $8.22 \%$ for proposed 
method.Fig. 13. illustrates the grid voltage and the injected current to the grid during the balanced operating condition. The power factoris around 0.99 and the current THD is very nearto the IEEE-519 constraints.

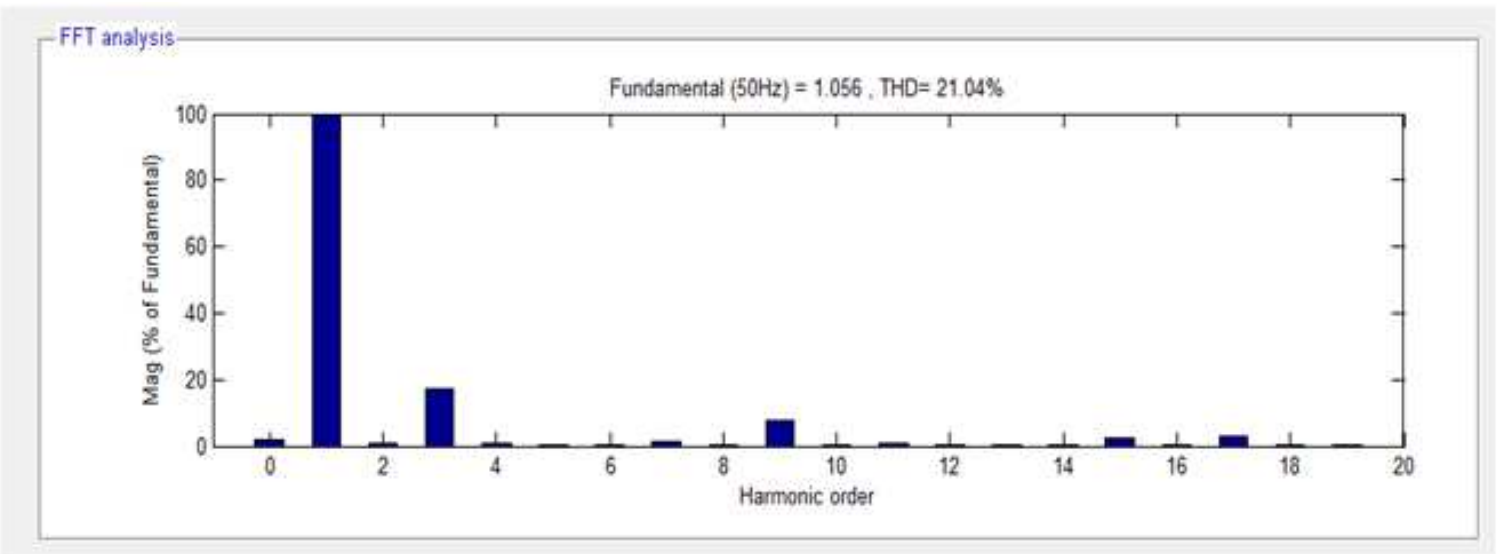

Figure 11: Harmonic spectrum of the inverter output current (OHSW PWM)-Conventional method

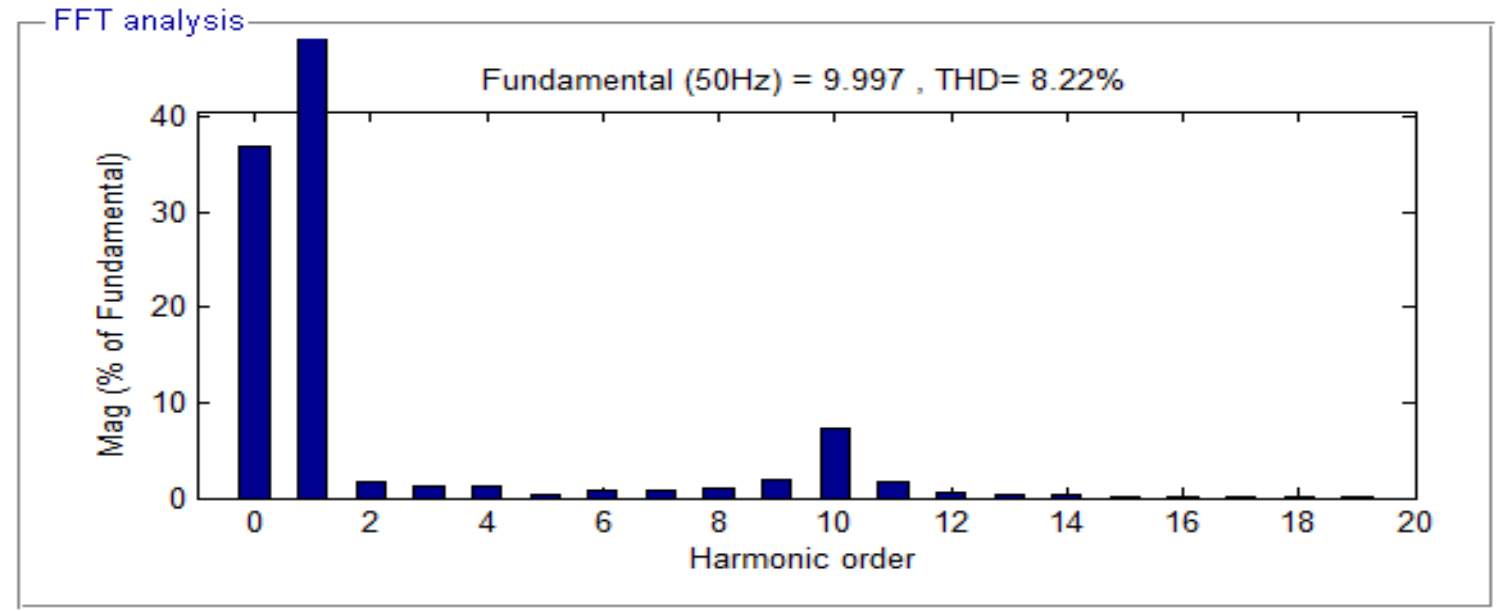

Figure 12: Harmonic spectrum of the inverter output current (DSAE PWM)-Proposed method

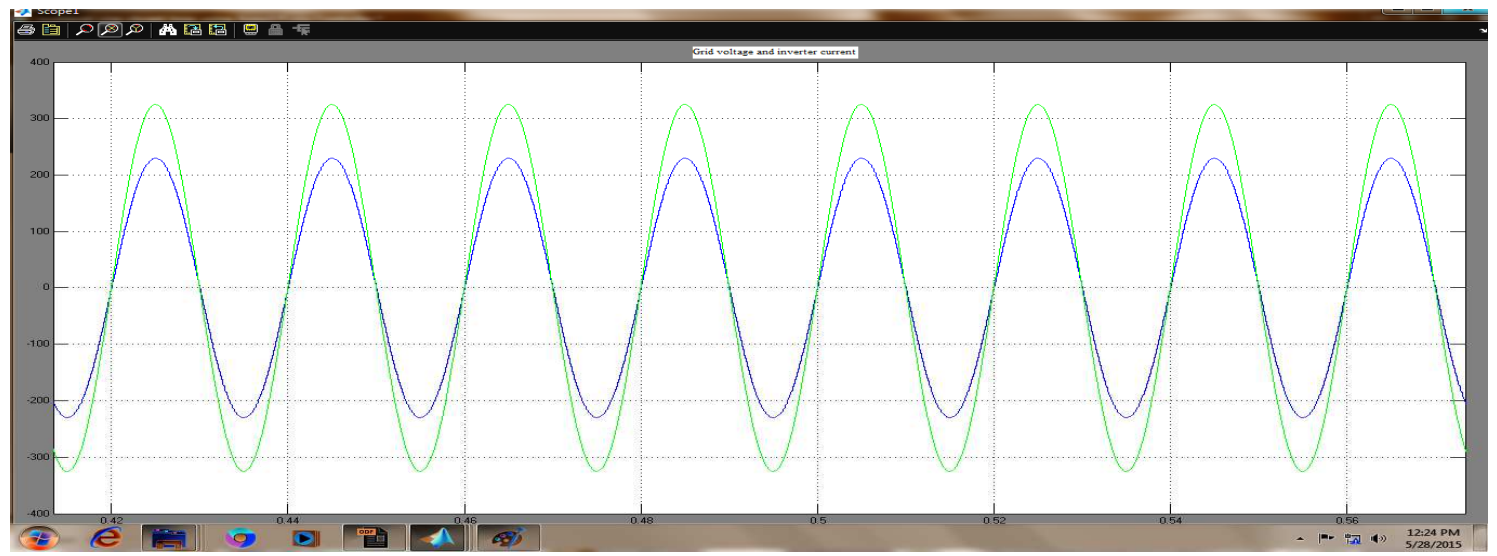

Figure 13: Grid voltage and Grid current are in phase at unity power factor

\section{CONCLUSIONS}

The Cascaded h-bridge multilevel inverter with DSAE PWM has been modeled and simulated using MATLAB for estimating the performance under various responses. It has been found from the simulated and experimental results that the 
cascaded h-bridge eleven level inverter with DSAE PWM perform better than conventional method (OHSW PWM) since it provides output with low distortion and higher fundamental RMS output voltage. It may be concluded that the Cascaded hbridge multilevel inverter based DSAE PWM technique can maintain the output voltage across the load side with reduction in total harmonic distortion.

\section{REFERENCES}

1 L. G. Franquelo, J. Rodriguez, J. I. Leon, S. Kouko, R. Portillo, M. A. M. Prats (2008) The age of multilevel converters arrives. IEEE Ind.Electron. Mag. 2(2) : pp 28-39

2 J.-S. Lai, F. Z. Peng (1996) Multilevel converters-A new breed of power converters.IEEE Trans. Ind. Appl. 32(3) : pp 509517

3 J. R. Rodriguez, J.-S. Lai, F. Z. Peng (2002) Multilevel inverters: A survey of topologies,control, and applications.IEEE Trans. Ind. Electron.49(4) : pp 724-738

1. Issaadi, Wassila. "Control of a photovoltaic system by fuzzy logic, comparative studies with conventional controls: results, improvements and perspectives." International Journal of Intelligent Engineering Informatics 5.3 (2017): 206-224.

4 L. M. Tolbert, F. Z. Peng, T. G. Habetler (1999) Multilevel converters for large electric drives. IEEE Trans. Ind. Appl.35(1) : pp 36-44

2. Tripathi, B. R. I. J. E. S. H., et al. "Feasibility study of commercial silicon solar PV module based low concentration photovoltaic system." International Journal of Electrical and Electronics Engineering Research 2.3 (2012): 84-93.

5 J. R. Rodriguez, J. W. Dixon, J. R. Espinoza, J. Pontt, P. Lezana (2005) PWM regenerative rectifiers: State of the art. IEEE Trans. Ind. Electron. 52(1): pp 5-22

6 C. Cecati, A. Dell'Aquila, M. Liserre, V. G. Monopoli (2003) Design of H-bridge multilevel active rectifier for traction systems. IEEE Trans. Ind. Appl. 39(5) : pp 1541-1550

3. Singh, A. N. A. N. D., and P. R. A. S. H. A. N. T. Baredar."A technical, economic, and environmental performance of hybrid (solar-biomassfuel cell) energy system." International Journal of Environment, Ecology, Family and Urban Studies (IJEEFUS), 6 (5), 1726 (2016).

7 C. Cecati, A. Dell'Aquila, M. Liserre, V. G. Monopoli (2003) A passivity based multilevel active rectifier with adaptive compensation for traction applications. IEEE Trans. Ind. Appl.39(5) :pp1404-1413

8 S. B. Kjaer, J. K. Pedersen, F. Blaabjerg (2005) A review of single-phase grid-connected inverters for photovoltaic modules. IEEE Trans. Ind. Appl. 41(5) : pp 1292-1306

4. ALRWASHDEH, SAAD S. "ENERGY OUTPUT EVALUATION FROM A PHOTOVOLTAIC SYSTEM AT DIFFERENT SELECTED SITES IN JORDAN." International Journal of Mechanical and Production Engineering Research and Development (IJMPERD), 2019. 9 (2): 467-476.

9 M. Calais, V. G. Agelidis (1998) Multilevel converters for single-phase grid connected photovoltaic systems-An overview. Proc. ISIE. 1: pp 224-229

10 M. Calais, V. G. Agelidis, L. J. Borle, M. S. Dymond (2000) A transformer less five level cascaded inverter based single phase photovoltaic system. Proc.IEEE 31stAnnu. Power Electron. Spec. Conf.3: pp 1173-1178

11 H. Ertl, J. W. Kolar, F. C. Zach (2002) A novel multicell DC-AC converter for applications in renewable energy systems. IEEE Trans. Ind. Electron.49(5) : pp 1048-1057 
12 O. Alonso, P. Sanchis, E. Gubia, L. Marroyo (2003) Cascaded H-bridge multilevel converter for grid connected photovoltaic generators with independent maximum power point tracking of each solar array. Proc. 34th IEEE Power Electron. Spec. Conf. 2 : pp 731-735

13 A. Rahiman, U. Kumar, V. Ranganathan (2004) A novel fifteen level inverter for photovoltaic power supply system. Conf. Rec. IEEE IASAnnu. Meeting : pp 1165-1171

14 F. S. Kang, S. J. Park, S. E. Cho, C. U. Kim, T. Ise (2005) Multilevel PWM inverters suitable for the use of stand-alone photovoltaic power grid-connected inverters for photovoltaic modules. IEEE Trans. Energy Convers.20(4) : pp 906-915

15 S. Alepuz, S. Busquets-Monge, J. Bordonau, J. Gago, D. Gonzalez, J. Balcells (2006) Interfacing renewable energy sources to the utility grid using a three-level inverter. IEEE Trans.Ind. Electron. 53(5) : pp 1504-1511

16 J. I. Leon, S. Vazquez, A. J. Watson, L. G. Franquelo, P. W. Wheeler, J. M. Carrasco (2009) Feed-forward space vector modulation for single-phase multilevel cascaded converters with any DC voltage ratio. IEEE Trans. Ind. Electron. 56(2) : pp $315-325$

17 F. J. T. Filho, T. H. A. Mateus, H. Z. Maia, B. Ozpineci, J. O. P. Pinto, L. M. Tolbert (2008) Real-time selective harmonic minimization in cascaded multilevel inverters with varying DC sources.Proc. IEEE Power Electron. Spec. Conf. : pp 43024306

18 R. Gonzalez, E. Gubia, J. Lopez, L. Marroyo (2008) Transformerless single-phase multilevel based

5. photovoltaic inverter. IEEE Trans. Ind. Electron. 55(7) : pp 2694-2702

19 E. Ozdemir, S. Ozdemir, L.M. Tolbert (2009) Fundamental frequency modulated six-level diodeclamped multilevel inverter for three-phase standalone photovoltaic system. IEEE Trans. Ind.

6. Electron.56(11): pp 4407-4415

20 M. Fortunato, A. Giustiniani, G. Petrone, G. Spagnuolo, M. Vitelli (2008) Maximum power point tracking in a one-cyclecontrolled single-stage photovoltaic inverter. IEEE Trans.Ind.Electron. 55(7) : pp. $2684-2693$

21 Shanthi.B, S.P.Natarajan (2010) FGPA based fuzzy logic control for single phase multilevel inverter. International journal of computer applications.9(3): pp $10-18$

22 F.T. Josh, Jovitha Jerome, J. Arulwilson (2012) Fuzzy Logic based nine level Inverter for photovoltaic systems. European Journal of Scientific Research.78(3) : pp 522-533

23 Jun Mei, Bailuxiao, Keshen, Leon M.Tolbert, Jian Yong Zheng (2013) Modular Multilevel Inverter with New Modulation Method and Its Application to Photovoltaic Grid-Connected Generator.IEEE Trans.Power Electron. 28(11) : pp. 5063 - 5073.

24 Liu, Y, Ge, B, Abu - Rub, H and Peng, FZ (2014) An effective control method for three phase and quasi z source cascaded multilevel inverter based grid - tie photovoltaic power system. IEEE Transactions on Industrial Electronics. 61(12) : pp. 6794 -6802 .

25 Alexander, SA andManigandanThathan(2015) Optimal Harmonic stepped waveform technique for solar fed Cascaded multilevel Inverter. Journal of Electrical Engineering and Technology. 10: pp. 742 - 751.

26 Coppola, M, Napoli, FD, Guerriero, P, Lannuzzi, D, Daliento, S and Pizzo, AD (2016) An FPGA based advanced control strategy of a grid tied PV CHB inverter. IEEE Transactions on Power Electronics. 31(1): pp. 806 - 816.

27 Lewicki, A and Morawiec, M (2017) Space-vector pulse width modulation for a seven-level cascaded H-bridge inverter with the control of DC-link voltages. Bulletin of the Polish Academy of Sciences Technical Sciences. 65(5): pp. 619-628. 